INFINITY-Jurnal Matematika dan Aplikasinya (IJMA)

Volume 1 | Nomor 2 | Maret|2021

\title{
Pengembangan Pembelajaran Matematika Siswa SMP: Koneksi Matematis Pada Realistik Mathematics Education
}

\section{Muhammad Hasbi1, Agung Lukito², Raden Sulaiman ${ }^{3}$}

Kata Kunci:

Pendidikan Matematika Realistik;

Koneksi Matematis; Model 4-D.

\begin{abstract}
Abstrak. Penelitian ini menjelaskan bagaimana proses dan hasil pengembangan pengajaran matematika berbasis pendidikan matematika realistik untuk meningkatkan kemampuan koneksi matematis siswa SMP. Model pengembangan bahan ajar mengacu pada model pengembangan 4-D Thiagarajan yang memiliki 4 langkah yaitu mendefinisikan, mendesain, mengembangkan, dan menyebarluaskan. Subjek penelitian adalah siswa kelas VIII SMPN 2 Candi Sidoarjo. Data penelitian diperoleh dengan lembar validasi, lembar observasi aktivitas guru dan siswa, angket respons siswa, dan tes kemampuan koneksi matematika. Produk dari penelitian ini adalah rencana pelaksanaan pembelajaran, lembar kerja siswa, dan tes kemampuan koneksi matematika. Hasil penelitian menunjukkan bahwa materi pembelajaran memenuhi syarat validitas, praktis, dan efektif. Hasil tes kemampuan koneksi matematis siswa meningkat berdasarkan t-tes berkorelasi dan analisis $\mathrm{N}$ gain. Oleh karena itu, dimungkinkan untuk mengatakan bahwa pengembangan pengajaran matematika berdasarkan pendidikan matematika yang realistis dapat meningkatkan kemampuan koneksi matematika. Sebagai saran, guru dalam mengelola pengajaran matematika sangat diperlukan untuk mengembangkan alat yang tepat, sehingga memiliki dampak positif pada hasil belajar siswa, terutama kemampuan koneksi matematika siswa.
\end{abstract}

\section{PENDAHULUAN}

Mata pelajaran matematika terdiri dari konsep-konsep yang saling terkait. Ini tidak hanya antar konsep dalam matematika, tetapi matematika juga berhubungan dengan disiplin ilmu lain, dan matematika berhubungan dengan kehidupan nyata. Hal ini 
didukung oleh pernyataan NCTM, "Matematika bukanlah kumpulan dari untaian atau standar yang terpisah, meskipun sering dipartisi dan disajikan dengan cara ini (Hasbi, Lukito, \& Sulaiman, 2019). Sebaliknya, matematika adalah bidang studi yang terintegrasi. Sejalan juga diungkapkan oleh (Markus, 2012) bahwa" Matematika bukanlah pengetahuan otonom yang bisa sempurna dengan sendirinya, tetapi membantu masyarakat dalam memahami dan menguasai permasalahan sosial, ekonomi, dan alam".

Oleh karena itu, kemampuan koneksi matematika sangat penting untuk dikembangkan dalam proses pembelajaran matematika. Hal ini didukung oleh pernyataan NCTM "Untuk membantu siswa membangun disposisi untuk menggunakan koneksi dalam memecahkan masalah matematika, daripada melihat matematika sebagai seperangkat konsep dan keterampilan yang terpisah dan terisolasi" (Hasbi et al., 2019). Hal ini mendukung tujuan pembelajaran matematika kurikulum 2013 bahwa "Tujuan pembelajaran matematika adalah agar siswa memahami konsep matematika, menjelaskan keterkaitan antar konsep dan menerapkan konsep atau algoritma secara fleksibel, tepat, efisien, dan tepat dalam pemecahan masalah" (Depdikbud, 2014). Demikian pula berdasarkan hasil penelitian yang menyatakan bahwa "Kemampuan koneksi matematika akan sangat dibutuhkan oleh siswa terutama untuk menyelesaikan masalah yang membutuhkan hubungan antara konsep matematika dengan konsep lain dalam matematika dan disiplin ilmu lain atau dalam kehidupan sehari-hari" (Rohendi \& Dulpaja, 2013). Keterampilan koneksi matematika penting tetapi siswa yang menguasai konsep matematika belum tentu memiliki koneksi matematika yang baik. Dalam suatu penelitian ditemukan bahwa siswa sering dapat menggunakan konsep matematika yang berkaitan dengan masalah nyata, tetapi hanya sedikit siswa yang dapat menjelaskan mengapa konsep tersebut digunakan dalam aplikasi (Bergeson, 2000). Oleh karena itu, kemampuan koneksi matematis sebagai aspek keterampilan matematika perlu dikembangkan oleh siswa.

Kemampuan koneksi matematika siswa di berbagai sekolah di Indonesia masih tergolong rendah dan sedang. Hal ini berdasarkan beberapa hasil penelitian yang menyebutkan bahwa kemampuan koneksi matematika siswa rendah dan siswa masih mengalami kesulitan dalam menghubungkan konsep matematika (Warih et al., 2016; Latif, 2017; Siregar \& Surya, 2017; Nugraha, 2018). Hal ini juga didukung oleh hasil survei PISA yang menunjukkan bahwa prestasi matematika di Indonesia pada jenjang SMP / SMA selalu dipatok pada angka rendah dan Indonesia berada pada peringkat 64 dari 72 negara dengan skor 386 (OECD, 2018). Dari masalah koneksi matematika rendah di atas dapat diketahui bahwa siswa tidak dapat membuat koneksi matematika sendiri. Hal ini didukung oleh pendapat yang mengatakan bahwa "Membuat koneksi adalah hal mendasar bagi pendidikan matematika mempengaruhi praktik mengajar mereka dalam beberapa hal penting. Efektivitas praktik mereka dibuktikan dengan contoh siswa di kelas yang diajar oleh para guru tersebut yang menunjukkan kemampuan membuat koneksi antara pengetahuan matematika dan bentuk lain dari pengetahuan disiplin dan antara pengetahuan matematika dan kehidupan nyata "(Sawyer, 2008). Faktor lain yang menyebabkan rendahnya kemampuan terhubung juga dikemukakan oleh "Salah satu penyebab rendahnya kemampuan koneksi matematis siswa terletak pada faktor pemodelan pembelajaran atau penggunaan metode pengajaran" (Ary et al., 2018).

Tujuan utama koneksi matematis ditekankan pada siswa yang berperan besar dalam membuat koneksi. Agar tujuan pembelajaran dapat mencapai target yang diharapkan maka perlu dilakukan pemilihan pendekatan pembelajaran yang sesuai, serta 
perlu dikembangkan perangkat pembelajaran yang mengikuti pendekatan pembelajaran yang digunakan. Pendekatan pembelajaran harus mampu membuat siswa aktif dalam kegiatan pembelajaran, menjadikan pembelajaran bermakna, dan mampu meningkatkan keterampilan koneksi matematis siswa. Hal tersebut didukung oleh pernyataan Haggarty dan Keynes bahwa "untuk meningkatkan proses belajar mengajar matematika di kelas diperlukan upaya untuk meningkatkan pemahaman guru, siswa, materi yang digunakan untuk pembelajaran dan interaksi antar mereka. Untuk tujuan pembelajaran agar dapat mencapai tujuan dengan baik, selain itu perlunya pemilihan metode dan strategi pembelajaran yang tepat, juga membutuhkan pengembangan perangkat pembelajaran yang sesuai dengan metode dan strategi pembelajaran yang digunakan" (Hasan, 2006). Berdasarkan uraian sebelumnya dapat disimpulkan bahwa permasalahan yang dihadapi peneliti disebabkan oleh kurangnya informasi atau bimbingan menggunakan perangkat pembelajaran yang nantinya dapat mengaktifkan siswa dalam kegiatan pembelajaran sehingga kegiatan pembelajaran berpusat pada siswa. Oleh karena itu diperlukan perangkat pembelajaran yang dapat memudahkan siswa dalam belajar, menghubungkan materi pembelajaran dengan kehidupan siswa sehari-hari, menghubungkan pembelajaran yang telah dipelajari siswa sebelumnya dengan pembelajaran saat ini. Salah satu alternatif pembelajaran yang dapat mengaktifkan siswa, membantu siswa mengasosiasikan konsep yang akan dipelajari dengan yang telah dipelajari dan menyesuaikan dengan kehidupan sehari-hari adalah pendekatan realistik.

Pendekatan realistik merupakan salah satu solusi untuk mengatasi permasalahan tersebut karena pendidikan matematika realistik menggunakan permasalahan kontekstual sebagai titik tolak pembelajaran. Menurut prinsip pendekatan realistik adalah keterlibatan siswa dalam matematika harus dimulai dalam konteks yang bermakna. Perkembangan pemahaman tersebut dan kemampuan menciptakan representasi matematis dimulai dari penalaran formal siswa (Web et al., 2011). Teori RME berfokus pada penemuan kembali itu sendiri melalui proses matematika dan memperhitungkan strategi dan interpretasi informal, melalui masalah kontekstual berdasarkan pengalaman nyata (Kwon, 2002). Pendekatan pembelajaran berbasis realistik juga dapat meningkatkan keterampilan koneksi matematis siswa. Hasilnya, kemampuan koneksi matematis siswa meningkat dengan pembelajaran berbasis pendekatan realistik. Siswa lebih antusias menggunakan pendekatan pembelajaran berbasis pendekatan realistik (Menanti et al, 2018).

\section{Pendidikan Matematika Realistik}

Realistic Mathematics Education (RME) adalah teori pengajaran khusus domain untuk pendidikan matematika (De Lange, 1987; Streefland, 1991; Gravemeijer, 1994; De Lange, 1996; Van den Heuvel-Panhuizen, 1996; Freudenthal, 2006; Treffers, 2012). Teori ini berasal dari belanda atas kebutuhan, yang dirasakan di seluruh dunia, untuk mereformasi pengajaran matematika. Berdasarkan gagasan Freudenthal bahwa matematika menjadi aktivitas manusia harus dihubungkan dengan kenyataan, dekat dengan anak-anak dan harus relevan dengan masyarakat, penggunaan konteks realistik merupakan salah satu ciri yang menentukan dari pendekatan pendidikan matematika (Freudenthal, 2012). Dalam RME, siswa harus belajar matematika dengan mengembangkan dan menerapkan konsep dan alat matematika dalam situasi masalah kehidupan sehari-hari yang masuk akal bagi mereka. Hal ini didukung oleh pernyataan 
bahwa "anak-anak belajar matematika dengan terlibat dalam memecahkan masalah dalam konteks yang bermakna bagi mereka" (Dickinson \& Hough, 2012).

Di satu sisi, kata sifat 'realistik' tentunya bersesuaian dengan bagaimana pembelajaran matematika terlihat di RME, tetapi di sisi lain, istilah ini juga membingungkan. Dalam bahasa Belanda, kata kerja 'zich realiseren' berarti 'membayangkan'. Dengan kata lain, istilah 'realistis' lebih mengacu pada niat bahwa siswa harus ditawarkan situasi masalah yang dapat mereka bayangkan daripada merujuk pada 'realitas' atau keaslian masalah (Freudenthal, 2006; Van den Heuvel-Panhuizen, 1996). Namun, yang terakhir ini tidak berarti bahwa hubungan dengan kehidupan nyata tidak penting. Ini hanya menyiratkan bahwa konteksnya tidak selalu terbatas pada situasi dunia nyata. Dunia fantasi dongeng dan bahkan dunia formal matematika bisa menjadi konteks yang sangat cocok untuk masalah, asalkan itu 'nyata' di benak siswa. Tiga prinsip panduan untuk desain instruksional RME harus dipertimbangkan (Gravemeijer, Cobb, Bowers, \& Whitenack, 2012).

\section{Koneksi Matematika}

Kemampuan koneksi matematis merupakan kemampuan yang harus dimiliki siswa dalam bidang matematika. Berpikir matematis melibatkan mencari koneksi, dan membuat koneksi membangun pemahaman matematika, tanpa koneksi, siswa harus belajar dan mengingat terlalu banyak konsep dan keterampilan yang terisolasi, dan dengan koneksi, mereka dapat membangun pemahaman baru tentang pengetahuan sebelumnya (NCTM, 2000). Tidak hanya koneksi matematis yang penting tetapi kesadaran akan perlunya koneksi dalam pembelajaran matematika juga penting. Jika diteliti tidak ada topik dalam matematika yang berdiri sendiri tanpa ada kaitannya dengan topik lain. Koneksi antar topik dalam matematika dapat dipahami oleh anak jika anak mengalami pembelajaran yang mempraktikkan keterampilan koneksi, salah satunya melalui pembelajaran bermakna (Bell, 1978). Hubungan antara proses dan konsep dalam matematika merupakan objek abstrak yang artinya hubungan tersebut terjadi dalam pikiran siswa, misalnya siswa menggunakan pikirannya ketika menghubungkan antara simbol dan representasi mereka (Hodgson, 1995).

Banyak siswa yang melihat matematika sebagai ilmu statis karena merasa matematika yang mereka pelajari tidak berkaitan dengan kehidupan mereka. Sangat sedikit siswa yang menganggap matematika sebagai ilmu yang dinamis, terutama karena lebih dari 99\% matematika yang mereka pelajari ditemukan oleh para ahli sebelum abad kedelapan belas (Johnson \& Litynsky, 1995). Ketika siswa dan guru terus "memikirkan hubungan", keterhubungan matematika akan tumbuh dan menjadi dominan. Ketika itu terjadi, maka akan bertanya-tanya mengapa ada orang yang pernah memikirkan matematika dengan cara lain (Coxford, 1995). Menurut Sawyer (2008), "Siswa harus kompeten dalam memahami hubungan antara matematika dan bentuk pengetahuan lain dan antara matematika dan pengalaman hidup mereka, serta kompeten dalam menerapkan pengetahuan matematika yang diperlukan untuk memaksimalkan produktivitas koneksi tersebut". Keindahan matematika terletak pada keterkaitannya dalam matematika itu sendiri. Bagi ahli matematika, hubungan ini tidak hanya keindahan matematika tetapi juga memunculkan teknik-teknik baru dalam memecahkan masalah. Jika siswa dapat membuat hubungan ini, mereka juga akan merasakan keindahan matematika (Cuoco, 1995). Berdasarkan beberapa pernyataan di atas dapat disimpulkan bahwa Mathematical connection adalah kemampuan siswa untuk (1) mengenali 
representasi padanan dari topik yang sama, (2) mengaitkan prosedur dalam satu representasi dengan prosedur dalam representasi padanan, dan (3) menggunakan dan menghargai hubungan antara matematika dan disiplin ilmu lainnya. Berdasarkan tinjauan pustaka, kami membuat hipotesis sebagai berikut:

H1: Bagaimana proses dan hasil pengembangan perangkat pembelajaran matematika realistik dengan menggunakan model pengembangan 4-D yang baik?

H2: Bagaimana keefektifan pembelajaran matematika realistik untuk meningkatkan kemampuan koneksi matematika siswa sekolah menengah?

\section{METODE}

Jenis penelitian ini adalah penelitian pengembangan. Model pengembangan yang digunakan adalah model pengembangan 4-D dari Thiagarajan yang meliputi empat tahap yaitu pendefinisian, perancangan, pengembangan dan diseminasi (Thiagarajan, 1974). Sampel penelitian ini terdiri dari siswa kelas VIII-A dan VIII-B dari populasi sampel kelas VIII yang berjumlah 70 siswa. Pengambilan sampel untuk pengujian pengembangan perangkat pembelajaran dilakukan di kelas VIII-A dan sampel untuk penyebaran perangkat pembelajaran dilakukan di kelas VIII-B. Perangkat pembelajaran yang akan dikembangkan berupa RPP, LKS, dan tes kemampuan koneksi matematis. Instrumen yang digunakan dalam penelitian ini meliputi instrumen untuk menilai validitas, reliabilitas, dan keefektifan perangkat pembelajaran yang dikembangkan. Alat pengumpulan data yang digunakan berupa lembar observasi, angket respon siswa, dan tes. Lembar tes kemampuan koneksi matematis terdiri dari 4 soal materi prisma. Lembar observasi terdiri dari mengamati aktivitas guru dan aktivitas siswa untuk melihat aktivitas siswa selama pembelajaran. Angket respon siswa digunakan untuk mendapatkan respon siswa terhadap perangkat yang telah digunakan selama pembelajaran. Sebelum dilakukan penelitian, instrumen tes, lembar observasi, dan angket respon siswa divalidasi oleh ahli yang terdiri dari 2 dosen dan 1 guru matematika. Uji validitas empiris tes kemampuan koneksi matematis. Sebelum digunakan untuk uji coba lapangan, soal tes matematika diujikan di luar subjek penelitian untuk mengukur validitas dan reliabilitas. Untuk mengukur validitas item dapat menggunakan rumus korelasi Product-Moment (Arikunto, 2012) berikut.

$$
\mathrm{r}_{\mathrm{xy}}=\frac{n \sum_{i=1}^{n} x_{i j} y_{i}-\left(\sum_{i=1}^{n} x_{i j} \sum_{i=1}^{n} y_{i}\right)}{\sqrt{\left\{n \sum_{i=1}^{n} x_{i j}^{2}-\left(\sum_{i=1}^{n} x_{i j}\right)^{2}\right\} \cdot\left\{n \sum_{i=1}^{n} y_{i}^{2}-\left(\sum_{i=1}^{n} y_{i}\right)^{2}\right\}}},
$$

Nilai koefisien validitas dikatakan valid jika koefisien validitas berkisar antara +1.00 hingga -1.00 (Fraenkel et al, 2011). Perhitungan koefisien reliabilitas butir soal tes menggunakan rumus Alpha-Cronbach (Urbina, 2004) sebagai berikut.

$$
\mathrm{r}_{11}=\left(\frac{n}{n-1}\right)\left(1-\frac{\sum_{i=1}^{n} \sigma_{i}^{2}}{\sigma_{t}^{2}}\right),
$$

Menurut Streiner (2003), "Instrumen dikatakan reliabel jika koefisien reliabilitas Alpha-Cronbach lebih dari 0,70 (ri>0,70) dan koefisien reliabilitas Alpha-Cronbach tidak mungkin lebih dari 0,90 ( $\mathrm{ri}<0,9$ )". Selanjutnya untuk menentukan peningkatan kemampuan koneksi matematis siswa pada materi prisma, hasil perhitungan selanjutnya dikategorikan dan dicocokkan dengan interpretasi berdasarkan kriteria pada Tabel 1 berikut. 


\begin{tabular}{lc}
\hline \multicolumn{1}{c}{ N-Gain } & Kriteria \\
\hline$(<\mathrm{g}>) \geq 0.70$ & Tinggi \\
$0,30 \leq(<\mathrm{g}>)<$ & Sedang \\
0.70 & Rendah \\
$(<\mathrm{g}>) \leq 0.30$ & \\
\hline
\end{tabular}

Sumber: (Hake, 1999)

Perangkat pembelajaran dikatakan baik jika dapat mendukung pembelajaran sehingga tujuan yang diharapkan dapat tercapai. Dalam penelitian ini perangkat pembelajaran dikatakan baik jika memenuhi kriteria valid, praktis dan efektif. Hal ini didukung oleh pernyataan bahwa "Komponen materi harus didasarkan pada state of the art knowledge (validitas isi) dan semua komponen harus secara konsisten dihubungkan satu sama lain (validitas konstruk), ciri kedua dari materi berkualitas tinggi adalah guru (dan ahli lainnya) menganggap materi dapat digunakan dan mudah bagi guru dan siswa untuk menggunakan materi dengan cara yang sebagian besar sesuai dengan perhatian pengembang, karakteristik ketiga dari materi berkualitas tinggi adalah siswa menghargai program pembelajaran dan pembelajaran yang diinginkan terjadi. Dengan materi yang efektif seperti itu, ada konsistensi antara kurikulum yang dimaksudkan dan pengalaman dan kurikulum yang dimaksudkan dan yang dicapai" (Nieveen, 1999).

Keefektifan pembelajaran dalam penelitian ini sebagai tolak ukur keberhasilan pembelajaran yang ditandai dengan aktivitas guru yang mengelola pembelajaran memenuhi kriteria baik, aktivitas siswa memenuhi kriteria aktif, respon siswa memenuhi kriteria positif, dan pembelajaran matematika realistik dapat meningkatkan kemampuan siswa, serta kemampuan koneksi matematika tercapai.

\section{HASIL DAN PEMBAHASAN}

Pada bagian ini dipaparkan hasil yang diperoleh.

\section{A. Deskripsi Pengembangan Perangkat Pembelajaran}

\section{Langkah Pendefinisian}

Perangkat pembelajaran matematika realistik untuk meningkatkan keterampilan koneksi matematika siswa pada materi prisma dikembangkan dengan menggunakan model pengembangan 4-D. Perangkat pembelajaran yang dikembangkan dalam penelitian ini meliputi RPP, LKS, dan tes kemampuan koneksi matematis. Proses pengembangan perangkat pembelajaran dimulai dengan tahap pendefinisian. Hasil analisis pada tahap ini digunakan untuk merancang perangkat pembelajaran pada tahap desain. Hasil draf pada tahap tersebut menghasilkan draf I.

\section{Langkah Perancangan}

Kemampuan koneksi matematis siswa diukur dengan mengembangkan alat penilaian hasil belajar berupa tes kemampuan koneksi matematika pada materi prisma. Soal tes kemampuan koneksi matematis siswa terdiri dari 4 soal berupa uraian. Sedangkan RPP, LKS, serta tes kemampuan koneksi matematika siswa dikembangkan dan disesuaikan dengan kurikulum 2013. 


\section{Langkah Pengembangan}

Setelah divalidasi oleh validator, peneliti merevisi pembelajaran sesuai saran validator yang menghasilkan draf II. Setelah semua perangkat pembelajaran memenuhi kriteria valid, selanjutnya dilakukan tes keterbacaan pada RPP, LKS, dan tes kemampuan koneksi matematis. Pada tahap ini, tes keterbacaan meliputi tes keterbacaan oleh guru mitra dan tes keterbacaan oleh siswa. Uji keterbacaan oleh guru mitra menyatakan bahwa perangkat pembelajaran dapat dibaca dan dipahami dengan jelas. Sedangkan pada tes keterbacaan oleh siswa, tiga siswa yang diminta untuk mengerjakan tes keterbacaan menyatakan bahwa secara umum mereka dapat membaca dan memahami kata atau kalimat dengan jelas. Sehingga peneliti tidak merevisi RPP, LKS, dan tes kemampuan koneksi matematis. Dengan demikian dapat dinyatakan bahwa perangkat pembelajaran matematika realistik yang dikembangkan sudah memenuhi kriteria perangkat pembelajaran yang baik dan dapat digunakan untuk uji coba. Berdasarkan kriteria kelayakan item yang telah dijelaskan sebelumnya, tingkat validitas tiap item berada pada kategori sedang dan tinggi dengan nilai koefisien validitas soal $1=0,697$, soal $2=0,745$, soal $3=0,862$, pertanyaan $4=0.788$. Sehingga setiap item dikatakan valid dan layak digunakan. Sedangkan dari hasil perhitungan uji reliabilitas diperoleh nilai koefisien reliabilitas sebesar 0,750. Dengan kriteria yang ditentukan maka dapat disimpulkan bahwa tes kemampuan koneksi matematika memiliki reliabilitas tes yang tinggi sehingga soal dikatakan valid dan layak digunakan.

Hasil analisis data menunjukkan bahwa skor masing-masing aspek penilaian dalam pembelajaran untuk pertemuan RPP 1 dan 2 adalah 3 dan 4 . Nilai tersebut berdasarkan kriteria kegiatan guru mengelola pembelajaran memenuhi kriteria dengan baik ( $\geq 3$ ) sehingga Draft II tidak perlu direvisi. Sedangkan mengamati hasil aktivitas siswa selama pembelajaran berlangsung pada RPP 1 dan RPP 2 mencapai toleransi waktu yang terdapat dalam RPP dengan toleransi $\leq 10 \%$ berdasarkan rentang waktu ideal yang telah ditetapkan karena aktivitas siswa memenuhi kriteria aktif, maka Draf II tidak perlu direvisi. Selanjutnya berdasarkan hasil angket respon siswa ditemukan respon siswa pada masing-masing aspek diatas 85\%, dengan demikian berdasarkan nilai tersebut respon siswa dapat dikatakan positif terhadap perangkat dan pembelajaran. Data hasil kemampuan koneksi matematis siswa diperoleh melalui pelaksanaan pretest dan posttest berupa tes tertulis berupa tes kemampuan koneksi matematis siswa yang digunakan untuk melihat apakah pembelajaran matematika realistik dapat meningkatkan kemampuan koneksi matematis siswa. Berdasarkan hasil analisis statistik uji-t yang berkorelasi dengan tes sisi kanan dan kriteria pengambilan keputusan diperoleh hasil T hitung < Ttabel $(-35,42<1,69)$ dengan (DK =n-2) (35-2). Hasil tersebut dapat dikatakan bahwa hipotesis alternatif (Ha) diterima dan hipotesis nol (H0) ditolak. Dengan demikian dapat disimpulkan bahwa terdapat perbedaan yang signifikan (dapat digeneralisasikan) keefektifan pembelajaran matematika realistik sebelum dan sesudah diberikan perlakuan. 
Kemampuan koneksi matematis siswa meningkat atau tidak dapat diketahui berdasarkan hasil analisis N-Gain. Ditemukan persentase siswa 62,85\% memperoleh NGain $\geq 0,7$ dan persentase siswa 37,15\% memperoleh $\mathrm{N}$-Gain $\geq 0,3$. Dengan demikian dapat disimpulkan bahwa pembelajaran matematika realistik dapat meningkatkan kemampuan koneksi matematis siswa. Rekapitulasi ketercapaian kriteria perangkat pembelajaran matematika realistik materi prisma disajikan di bawah ini.

\begin{tabular}{clc}
\multicolumn{2}{c}{ Tabel 2. Kriteria Pencapaian Pengembangan Perangkat Pembelajaran } \\
\hline Kriteria & \multicolumn{1}{c}{ Aspek } & Keterangan \\
\hline \multirow{3}{*}{ Valid } & Validasi Ahli & Valid \\
& Validititas & Tinggi dan \\
& Rediabiliti & Tinggi \\
\multirow{5}{*}{ Praktis } & Aktivitas guru dalam pembelajaran & Baik \\
& Aktivitas Siswa & Aktif \\
& Respons Siswa & Positif \\
Efektif & Peningkatan kemampuan koneksi & \\
& matematis siswa & Tercapai \\
\end{tabular}

\section{B. Deskripsi efektivitas pembelajaran}

\section{Langkah Diseminasi/Penyebaran}

Tahap diseminasi dilakukan secara terbatas yaitu peneliti hanya mendistribusikannya ke satu kelas selain kelas penelitian untuk mengetahui keefektifan pembelajaran dengan menggunakan perangkat pembelajaran yang baik yang dihasilkan pada tahap pengembangan. Data hasil kemampuan koneksi matematis siswa diperoleh melalui pelaksanaan pretest dan posttest berupa tes tertulis berupa tes kemampuan koneksi matematis siswa yang digunakan untuk melihat apakah pembelajaran matematika realistik dapat meningkatkan kemampuan koneksi matematis siswa. Berdasarkan hasil analisis statistik uji-t yang berkorelasi dengan uji sisi kanan dan kriteria pengambilan keputusan diperoleh hasil Thitung <Ttabel $(-31,38<1,69)$ dengan (dk n-2) (35-2). Hasil tersebut dapat dikatakan bahwa hipotesis alternatif (Ha) diterima dan hipotesis nol (H0) ditolak. Dengan demikian dapat disimpulkan bahwa terdapat perbedaan yang signifikan (dapat digeneralisasikan) keefektifan pembelajaran matematika realistik. Selain itu, berdasarkan hasil analisis $\mathrm{N}$-Gain didapatkan persentase siswa 42,85\% memperoleh $\mathrm{N}$-Gain $\geq 0,7$ dan persentase siswa 57,15\% memperoleh $\mathrm{N}$ Gain $\geq 0,3$. Dengan demikian dapat disimpulkan bahwa pembelajaran matematika realistik dapat meningkatkan kemampuan koneksi matematis siswa pada materi prisma.

Berdasarkan uraian di atas, pembelajaran matematika realistik pada materi prisma dinyatakan efektif, karena memenuhi kriteria sebagai berikut: (a) Aktivitas guru dalam pembelajaran memenuhi katogori baik, (b) Aktifitas siswa aktif, (c) Respons siswa terhadap pembelajaran positif, (d) Penguasaan pembelajaran klasikal tercapai, (e) 
Pembelajaran matematika realistik untuk melatih keterampilan koneksi matematis siswa tercapai.

\section{KESIMPULAN} berikut:

Berdasarkan hasil analisis dan pembahasan, maka diperoleh kesimpulan sebagai

1. Perangkat pembelajaran matematika realistik yang dikembangkan dengan menggunakan model pengembangan 4-D memenuhi kriteria perangkat berkualitas baik yang ditunjukkan dengan kriteria valid, praktis, dan efektif.

a. Perangkat pembelajaran dinyatakan valid oleh validator.

b. Tes Kemampuan Koneksi Matematis memenuhi kriteria yang valid dan reliabel.

c. Kegiatan guru mengatur pembelajaran dengan baik.

d. Aktivitas siswa dalam pembelajaran aktif.

e. Respon siswa terhadap pembelajaran yang positif.

f. Pembelajaran matematika realistik dapat meningkatkan kemampuan koneksi matematika siswa yang dicapai.

2. Keefektifan pembelajaran matematika realistik tercapai, hal ini ditunjukkan dengan memenuhi kriteria sebagai berikut, (a) Aktivitas guru dalam pembelajaran baik, (b) Aktifitas siswa aktif, (c) Respon siswa yang positif, (d) Pembelajaran matematika realistik dapat meningkatkan kemampuan koneksi matematis siswa yang dicapai.

\section{REFERENSI}

Ary, D., Jacobs, L. C., Irvine, C. K. S., \& Walker, D. (2018). Introduction to research in education. Cengage Learning.

Arikunto, S. (2012). Dasar-dasar evaluasi pendidikan edisi 2. Jakarta: Bumi Aksara.

Bell, F. H. (1978). Teaching and learning mathematics (in secondary schools). WC Brown Company.

Bergeson, T. (2000). Teaching and learning mathematics. State Superintendent of Public Instruction, Washington.

Cuoco, A. A., Goldenberg, E. P., \& Mark, J. (1995). Connecting geometry with the rest of mathematics. Connecting mathematics across the curriculum, 183-197.

Coxford, A. F. (1995). The Case for Connection. Connecting Mathematics Across the Curriculum. Editor. House, P. A. Dan Coxford, A, F. Reston, Virginia: NCTM.

Depdikbud. (2014). Permendikbud No. 58 Tahun. 2014 Tentang Kurikulum 2013 Sekolah Menengah Pertama/Madrasah Tsanawiyah. Jakarta: Depdikbud.

De Lange, J. (1987). Mathematics, insight and meaning. University.

De Lange, J. (1996). Using and applying mathematics in education. In International handbook of mathematics education (pp. 49-97). Springer, Dordrecht.

Dickinson, P., \& Hough, S. (2012). Using realistic mathematics education in UK classrooms. Centre for Mathematics Education, Manchester Metropolitan University, Manchester, UK.

Fraenkel, J. R., Wallen, N. E., \& Hyun, H. H. (2011). How to design and evaluate research in education. New York: McGraw-Hill Humanities/Social Sciences/Languages.

Freudenthal, H. (2012). Mathematics as an educational task. Springer Science \& Business Media. 
Freudenthal, H. (2006). Revisiting mathematics education: China lectures (Vol. 9). Springer Science \& Business Media.

Gravemeijer, K., Cobb, P., Bowers, J., \& Whitenack, J. (2012). Symbolizing, modeling, and instructional design. In Symbolizing and communicating in mathematics classrooms (pp. 235-284). Routledge.

Gravemeijer, K. P. (1994). Developing realistic Mathematics Education (Ontwikkelen van realistisch reken/wiskundeonderwijs). Freudenthal Institute, Utrecht, The Netherlands.

Haji, S., Abdullah, M. I., Maizora, S., Yumiati. (2017). Developing Student's Ability of Mathematical Connection Through Using Outdoor Mathematics Learning. Journal of Mathematics Education. Vol 6, No. 1.

Hake, R. R. (1999). Analyzing change/gain scores. Unpublished. [online] URL: http://www. physics. indiana. edu/ sdi/AnalyzingChange-Gain. pdf.

Hasan, Ü. N. A. L. (2006). Preservice Secondary Mathematics Teachers'comparative Analyses of Turkish and American High School Geometry Textbook. Measurement, 436(482), 487.

Hasbi, M, Lukito, A., \& Sulaiman, R. (2019). Mathematical Connection Middle-School Students 8 th in Realistic Mathematics Education. Journal of Physics: Conference Series, 1417(1), 012047. IOP Publishing. https://doi.org/10.1088/1742-6596/1417/1/012047

Hasbi, Muhammad, Lukito, A., Sulaiman, R., \& Muzaini, M. (2019). Improving the Mathematical Connection Ability of Middle-School Students through Realistic Mathematics Approach. Journal of Mathematical Pedagogy (JoMP), 1(1), 37-46.

Hendriana, H., Slamet, U. R., \& Sumarmo, U. (2014). Mathematical connection ability and selfconfidence (an experiment on junior high school students through contextual teaching and learning with mathematical manipulative). International Journal of Education, 8(1), 1-11.

Hodgson, T. R. (1995). Connections as problem-solving tools. Connecting mathematics across the curriculum, 13-21.

Johnson, K. M., \& Dan Litynsky, C. L. (1995). Breathing Life into Mathematics. Connecting Mathematics across the Curriculum Editor: House, PA dan Oxford, AF Reston, Virginia: NCTM.

Kline, R. B. (2015). Principles and practice of structural equation modeling. Guilford publications.

Kwon, O. N. (2002). Conceptualizing the Realistic Mathematics Education Approach in the Teaching and Learning of Ordinary Differential Equations. Journal of the Korea Society of Mathematical Education Series: Research in Mathematical Education Vol. 6, No. 2.

Latif, S. (2017). Mathematical Connection Ability in Solving Mathematics Problem Based On Initial Abilities Of Students At SMPN 10 Bulukumba. Daya Matematis: Jurnal Inovasi Pendidikan Matematika, 4(2), 207-217.

Markus, K. A. (2012). Principles and Practice of Structural Equation Modeling by Rex B . Kline. In Book Review (Vol. 5511). https://doi.org/10.1080/10705511.2012.687667

Menanti, H., \& Sinaga, B. (2018). Improve Mathematical Connections Skills with Realistic Mathematics Education Based Learning. In 3rd Annual International Seminar on Transformative Education and Educational Leadership (AISTEEL 2018). Atlantis Press.

National Council of Teachers of Mathematics (NCTM). (2000). Principles and Standards Schools Mathematics. Reston, VA: NCTM.

Nieveen, N. (1999). Prototyping to reach product quality. In Design approaches and tools in education and training (pp. 125-135). Springer, Dordrecht. 
Nugraha, A. A. (2018). Analisis Kemampuan Koneksi Matematis Siswa SMP pada Materi Sistem Persamaan Linear Dua Variabel (SPLDV). Suska Jurnal of Mathematics Education. Vol. 4, No $1,59-64$.

OECD. (2018). PISA 2015 Results in Focus. New York: Columbia University.

Rohendi, D., \& Dulpaja, J. (2013). Connected Mathematics Project ( CMP ) Model Based on Presentation Media to the Mathematical Connection Ability of Junior High School Student. Journal of Education and Practice, 4(4), 17-22.

Sawyer, A. (2008). Making connections: Promoting connectedness in early mathematics education. Navigating currents and charting directions, 429-435.

Siregar, N. D., \& Surya, E. (2017). Analysis of students' junior high school mathematical connection ability. International Journal of Sciences: Basic and Applied Research (IJSBAR), 33(2), 309320.

Saminanto, K. (2015). Analysis of mathematical connection ability in linear equation with one variable based on connectivity theory. International Journal of Education and Research, 3(4), 259-270.

Streefland, L. (1991). Fractions in realistic mathematics education: A paradigm of developmental research (Vol. 8). Springer Science \& Business Media.

Streiner, D. L. (2003). Starting at the beginning: an introduction to coefficient alpha and internal consistency. Journal of personality assessment, 80(1), 99-103.

Thiagarajan, S. (1974). Instructional development for training teachers of exceptional children: A sourcebook.

Treffers, A. (2012). Three dimensions: A model of goal and theory description in mathematics instruction-The Wiskobas Project (Vol. 3). Springer Science \& Business Media.

Urbina, S. (2004). Essentials of Psychological Testing. New Jersey: John Wiley \& Sons.

Van den Heuvel-Panhuizen, M. H. A. M. (1996). Assessment and realistic mathematics education (Vol. 19). Utrecht University.

Warih, S., Dwi, P., Parta, I. N., \& Rahardjo, S. (2016). Analisis kemampuan koneksi matematis siswa kelas VIII pada materi teorema Pythagoras. Konferensi Nasional Penelitian matematika dan Pembelajarannya (KNKMP I). Surakarta: Universitas Muhammadiyah Surakarta.

Webb, D. C., Van der Kooij, H., \& Geist, M. R. (2011). Design research in the Netherlands: Introducing logarithms using realistic mathematics education. Journal of Mathematics Education at Teachers College, 2(1). 